\title{
Neformalna dugotrajna skrb za starije i nemoćne osobe
}

\author{
MARIJANA BAĐUN, Institut za javne financije
}

Starenje stanovništva glavni je pokretač rastuće potražnje za dugotrajnom skrbi, što vodi do sve većeg pritiska na javne financije. Neformalna skrb za starije i nemoćne osobe stvara mnoge koristi, pa tako i uštede za državni proračun, no u Hrvatskoj se malo zna o problemima s kojima se suočavaju pružatelji neformalne skrbi. U Newsletteru se prikazuju podaci o raširenosti neformalne skrbi, navode raspoloživa prava za pružatelje i primatelje neformalne skrbi u Hrvatskoj, te se predlažu mjere za unaprjeđenje sustava neformalne skrbi o starijim i nemoćnim osobama u Hrvatskoj temeljem primjera iz drugih zemalja EU-a.

\section{UvoD}

Dugotrajna skrb niz je usluga osobama smanjenih funkcionalnih mogućnosti (fizičkih ili kognitivnih), ovisnih o tuđoj pomoći u dužem razdoblju. Pomoć se može odnositi na obavljanje osnovnih svakodnevnih aktivnosti (hranjenje, kupanje, odijevanje, ustajanje iz kreveta, odlazak na WC) i/ili instrumentalnih svakodnevnih aktivnosti (kupovina, pranje odjeće, pospremanje, kuhanje, upravljanje financijama, telefoniranje itd.). Dugotrajna skrb može biti formalna - u institucijama poput domova za starije i nemoćne ili izvaninstitucionalna (npr. socijalna usluga pomoći u kući) - i neformalna (obično obiteljska i neplaćena). Potražnja za dugotrajnom skrbi izrazito ovisi o dobi; u većini je OECD zemalja svaka peta osoba koja prima dugotrajnu skrb mlađa od 65 godina, dok je otprilike polovica korisnika starija od 8 o godina (OECD, 2OII).

Iako građanima ne bi trebalo nametati obvezu skrbi o starijim i nemoćnim članovima obitelji, ipak su koristi od neformalne skrbi trostruke (OECD, 2OII). Prvo, osobe kojima treba pomoć preferiraju da o njima brinu članovi obitelji i prijatelji. Drugo, pružatelji skrbi trebali bi se osjećati dobro jer to rade za ljude koje vole. Treće, raspoloživost neformalne skrbi znatno smanjuje državne rashode. Procijenjena ekonomska vrijednost neformalne skrbi uvelike nadmašuje vrijednost formalne. U Europi je ekonomska vrijednost neplaćenog obiteljskog rada (kućanski poslovi, briga o djeci te starijim i nemoćnim ukućanima) procijenjena na - ovisno o korištenoj metodi - između 20 i 37\% europskog BDP-a (Gianelli i sur., 20Io).

U Hrvatskoj država ima skromnu ulogu u skrbi o starijima, a okosnicu sustava dugotrajne skrbi čini obitelj. Prema istraživanju Podgorelec i Klempić (2007), najčešći su pružatelji skrbi bračni partneri (u većem broju supruge nego supruzi), zatim odrasla djeca (češće kćeri), potom drugi članovi obitelji, a tek na kraju prijatelji i susjedi. Samo je oko $2 \%$ hrvatskog stanovništva starijeg od 65 godina smješteno u domove za starije i 
nemoćne osobe (MSPM, 20I3), dok je prosjek EU-a oko 5\%. Odgovornost obitelji za dobrobit starijih osoba ima uporište i u Ustavu RH (čl. 64): "Djeca su dužna brinuti se za stare i nemoćne roditelje."

\section{RAŠIRENOST NEFORMALNE SKRBI}

U OECD zemljama, jedna od deset odraslih osoba neformalno (obično neplaćeno) skrbi/njeguje osobe s funkcionalnim ograničenjima (OECD, 2OII). Udio pružatelja neformalne skrbi u ukupnom stanovništvu kreće se od 8 do I6\%, a dvije trećine su žene. U više od polovice slučajeva radi se o njezi niskog intenziteta (manje od Io sati tjedno), kakva njega prevladava u zemljama sjeverne Europe, dok je u južnoj Europi više od 30\% neformalne njege intenzivno (preko 20 sati tjedno). U Španjolskoj je primjerice udio intenzivne njege oko 50\%. Pritom valja napomenuti da mediteranske zemlje imaju općenito nešto veći udio starijih koji žive s djecom, dok sjeverne članice EU-a imaju najmanji udio (Žganec i sur., 2008). U zemljama OECD-a jedna od pet osoba starijih od 50 godina s nekim oblikom ograničenja dnevnih aktivnosti prima neformalnu skrb, a taj se udio udvostručuje kod osoba s dva ili više ograničenja.

Prema Izvješću Europske komisije (EC, 20I5), skrb za starije u okviru obitelji u Hrvatskoj je iznad prosjeka EU-a: oko I7\% osoba u dobi od 35 do 49 godina mora brinuti o starijim članovima obitelji barem nekoliko puta tjedno. Ukupni podaci o tome koliko osoba pruža neformalnu skrb nisu poznati, ali više bi informacija trebalo biti dostupno nakon što bude provedeno SHARE (Survey of Health, Ageing and Retirement in Europe) istraživanje za Hrvatsku koje je u tijeku. Prema podacima Europske komisije (EC, 2015a), Hrvatska je 2013. imala 274 tisuće funkcionalno ovisnih ljudi. Od toga je I6 tisuća bilo u institucijama, I7 tisuća primalo je formalnu kućnu njegu, a Io8 tisuća novčane naknade. Može se pretpostaviti da su ostali (I33 tisuće) primali neformalnu skrb, kao i oni koji su dobivali novčane naknade, pa se ukupno radilo o 24I tisući osoba. Prema osnovnom scenariju projekcija Europske komisije, taj će se broj do 2060. povećati za 20 tisuća.

\section{Grafikon I.}

Osobe s poteškoćama u obavljanju svakodnevnih aktivnosti koje trebaju i koriste pomoć druge osobe prema dobnim skupinama (u tis.)

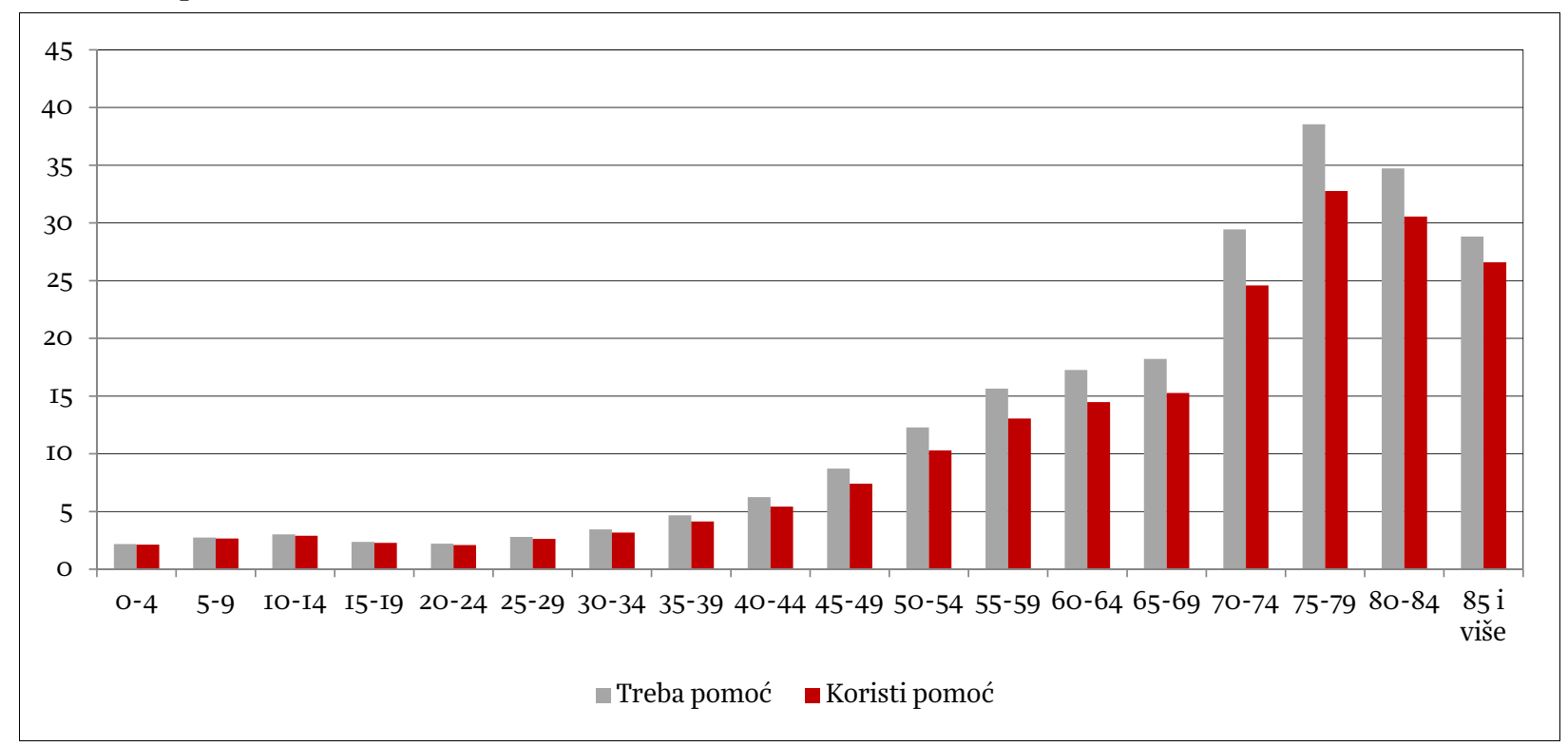

Izvor: DZS (2OI3).

U popisu stanovništva 2OII. prikupljani su podaci i o stanovništvu s teškoćama u obavljanju svakodnevnih aktivnosti. Ukupno ih je bilo oko 760 tisuća, a primjerice u dobnoj skupini stanovnika od 65 do 69 godina, $35 \%$ imalo je takve poteškoće, dok je u skupini od 8 o do 84 godine $59 \%$ imalo poteškoće (DZS, 2O13). Pomoć druge osobe u obavljanju svakodnevnih aktivnosti ukupno je trebalo 233 tisuće stanovnika; od toga je oko 
I50 tisuća starijih od 65 godina. Pomoć druge osobe koristilo je 202 tisuće ljudi, a među njima je starijih od 65 godina bilo oko I3o tisuća, odnosno oko dvije trećine. Na grafikonu I jasno se vidi kako potreba za pomoći druge osobe raste s dobi, a najveći broj osoba kojima treba pomoć i koji primaju pomoć u dobnoj je skupini od 75 do 79 godina. Nakon toga broj opada zbog veće smrtnosti. Među osobama starijim od 65 godina koje trebaju i primaju pomoć, 70\% su žene, što je posljedica činjenice da žene žive duže. U svim dobnim skupinama prije 65 godina starosti više je muškaraca koji koriste pomoć nego žena.

\section{PodršKa NEFormalnoj SKRBi}

Istraživanja pokazuju kako postoji potencijal za povećanje intenziteta neformalne skrbi. Međutim, intenzivna skrb (preko 20 sati tjedno) povezana je sa smanjenjem ponude radne snage: pružatelji skrbi imaju manju vjerojatnost zaposlenosti od onih koji ne pružaju skrb. Isto tako, pružatelji skrbi koji su zaposleni rade u prosjeku dva sata tjedno manje od onih koji ne pružaju skrb i češće rade nepuno radno vrijeme (OECD, 2OII). Manja zaposlenost i kraće radno vrijeme mogu utjecati na veći rizik siromaštva. Pružatelji intenzivne skrbi također imaju veću učestalost psihičkih problema od onih koji ne pružaju skrb budući da je briga o članovima obitelji stresna i zahtjevna. To je posebno izraženo kod njegovatelja koji stanuju s osobom koju njeguju. Pored toga, skrb o članu obitelji može povećati rashode kućanstva za grijanje, lijekove, prijevoz, medicinsku pomoć itd. Poteškoće s kojima se suočavaju pružatelji neformalne skrbi upućuju na to da bi im država trebala nekako pomoći. Kakvo je stanje u Hrvatskoj?

\section{I. NAKNADE}

Praksa zemalja OECD-a je da pružatelji ili/i primatelji neformalne skrbi dobivaju naknade za skrb. U Hrvatskoj je naglasak stavljen na pomoć primateljima skrbi, kao što je i u npr. Češkoj, Francuskoj, Italiji, Poljskoj i Španjolskoj. Prema Zakonu o socijalnoj skrbi (čl. 57), osobi koja ne može sama udovoljiti osnovnim životnim potrebama, uslijed čega joj je prijeko potrebna pomoć u dnevnim aktivnostima, priznaje se pravo na doplatak za pomoć i njegu. Međutim, to pravo ne može ostvariti ako:

- ima sklopljen ugovor o doživotnom ili dosmrtnom uzdržavanju;

- ima u vlasništvu drugi stan ili kuću, osim onih koje koristi za stanovanje, a koji može prodati ili iznajmiti i tako osigurati sredstva za pomoć i njegu;

- ima u vlasništvu poslovni prostor koji ne koristi za obavljanje registrirane djelatnosti;

- prosječni mjesečni prihod samca prelazi I.25o kn, odnosno prosječni mjesečni prihod članova kućanstva prelazi I.ooo kn u prethodna tri mjeseca prije mjeseca u kojem je podnesen zahtjev;

- doplatak za pomoć i njegu može ostvariti po posebnom propisu;

- ima priznato pravo na osobnu invalidninu;

- ima osiguran institucijski smještaj.

Pravo na doplatak za pomoć i njegu može se priznati u punom ili smanjenom iznosu, ovisno o potrebnom intenzitetu njege. Visina doplatka je 500 , odnosno $350 \mathrm{kn} .{ }^{2}$ Ako se radi o osobi s težim invaliditetom, težim trajnim promjenama u zdravstvenom stanju te slijepoj, gluhoj i gluhoslijepoj osobi koja nije osposobljena za samostalni život i rad, onda se kod ostvarivanja prava ne uzima u obzir dohodovni i imovinski status već se ostvaruje doplatak u punom iznosu (50o kn). Isto vrijedi i za osobe lišene poslovne sposobnosti te za slijepe, gluhe i gluhoslijepe osobe koje su osposobljene za samostalan život i rad, ali one ostvaruju doplatak u smanjenom iznosu.

\footnotetext{
${ }^{\mathrm{I}}$ I.250 kn je 250\% osnovice na temelju koje se izračunava iznos drugih prava iz sustava socijalne skrbi, koja iznosi 500 kn, a I.ooo $\mathrm{kn}$ je 200\% navedene osnovice.

${ }^{2} 500 \mathrm{kn}$ je IOO\% osnovice na temelju koje se izračunava iznos drugih prava iz sustava socijalne skrbi, a $350 \mathrm{kn}$ čini $70 \%$ navedene osnovice.
} 
Doplatak za pomoć i njegu, ostvaren prema Zakonu o socijalnoj skrbi, 20I4. koristilo je 72.408 osoba (MSPM, 20I5), pri čemu ih je otprilike polovica bila starija od 65 godina (MSPM, 2014). Dvije trećine korisnika primalo je doplatak u punom iznosu, a ostatak u smanjenom. Iz proračuna je 20I4. za doplatak za pomoć i njegu ostvaren prema Zakonu o socijalnoj skrbi izdvojeno 407,7 mil. kn (oko 470 kn mjesečno po osobi). Do 3I. prosinca 1998. doplatak za pomoć i njegu ostvarivao se prema Zakonu o mirovinskom osiguranju. U prosincu 20I4. bilo je 8.669 korisnika tog doplatka, koji je prosječno mjesečno iznosio 783 kn (HZMO, 2OI5), a državni su rashodi za doplatak ostvaren prema Zakonu o mirovinskom osiguranju 20I4. iznosili 86,I mil. kn.

Kad je korisnik doplatka u zdravstvenoj ili drugoj ustanovi dulje od I5 dana, pravo na doplatak miruje. Korisniku prava na doplatak za pomoć i njegu prema Zakonu o socijalnoj skrbi iznimno se može priznati i pomoć u kući za zadovoljenje pojedine potrebe iz dnevnih aktivnosti koju mu ne mogu pružiti članovi obitelji. Inače se pravo na tu socijalnu uslugu ne priznaje osobama kojima pomoć mogu pružiti roditelj, bračni drug i djeca (čl. 8o Zakona o socijalnoj skrbi). Ta usluga ulazi u domenu formalne kućne skrbi.

Osobna invalidnina (čl. 54 Zakona o socijalnoj skrbi) priznaje se osobi s teškim invaliditetom ili drugim teškim trajnim promjenama u zdravstvenom stanju, u svrhu uključivanja u svakodnevni život zajednice. Pravo na osobnu invalidninu ne može se priznati osobi kojoj je priznato pravo na doplatak za pomoć i njegu, a ostali ograničavajući čimbenici za ostvarivanje prava vrlo su slični onima kod doplatka. Invalidnina za osobu koja nema vlastiti prihod mjesečno iznosi $1.250 \mathrm{kn}^{3}$, a ako osoba ostvaruje prihod po bilo kojoj osnovi, onda se invalidnina utvrđuje kao razlika navedenog iznosa i prosječnog prihoda ostvarenog $\mathrm{u}$ prethodna tri mjeseca prije mjeseca $\mathrm{u}$ kojem je podnesen zahtjev. ${ }^{4} \mathrm{U}$ 20I4. osobnu invalidninu primalo je 23.740 korisnika (MSPM, 2015), a manje od I\% starije je od 65 godina (MSPM, 20I4). Iz proračuna je za tu svrhu u 20I4. izdvojeno 354,8 mil. kn, što je oko I.245 kn mjesečno po korisniku.

Hrvatski zakoni ne predviđaju mogućnost ostvarivanja statusa njegovatelja za starije i nemoćne osobe, već samo za djecu s teškoćama u razvoju ili osobe s invaliditetom (čl. 63 Zakona o socijalnoj skrbi) te hrvatske ratne vojne invalide iz Domovinskog rata (HRVI) prve skupine - invalidi sa IOo\% oštećenja organizma kojima je za redoviti život potrebna njega i pomoć druge osobe (čl. 85 ZOPHBDR-a). Njegovatelji imaju pravo na naknadu, prava iz zdravstvenog i mirovinskog osiguranja i prava za vrijeme nezaposlenosti, kao zaposlena osoba po posebnim propisima, a sredstva za tu namjenu osiguravaju se državnim proračunom. Za djecu s teškoćama u razvoju, odnosno osobe s invaliditetom, njegovatelj može biti roditelj, a iznimno i drugi članovi obitelji. Njegovatelji HRVI mogu biti članovi obitelji (osim djece dok se školuju), nezaposlene osobe, umirovljenici i stranci, a mjerila za izbor osobe koja može pružati njegu i pomoć, te postupak i način ostvarivanja prava propisani su posebnim pravilnikom. ${ }^{5}$

Status roditelja njegovatelja 20I4. imalo je 3.279 osoba, a status njegovatelja 69 osoba (MSPM, 2OI5). Neto naknada za roditelja njegovatelja ili njegovatelja iznosi $2.500 \mathrm{kn}^{6}$ mjesečno, a iz proračuna je za njih izdvojeno I37 mil. kn (oko 3.4Io kn bruto mjesečno po osobi, u što su uključeni i obvezni doprinosi). Njegovatelja HRVI prve skupine bilo je 20I3. prosječno mjesečno 437, za koje je iz proračuna izdvojeno 28,9 mil. kn (oko 5.5Io kn bruto mjesečno po osobi), a njihova je neto plaća jednaka iznosu osobne invalidnine HRVI prve skupine. Više o osobnoj invalidnini i doplatku za pomoć i njegu HRVI (koji se međusobno ne isključuju) prema ZOPHBDR-u, može se pronaći u okviru I.

\footnotetext{
${ }^{3}$ I250 kn je 250\% osnovice na temelju koje se izračunava iznos drugih prava, a koja iznosi 500 kn.

${ }_{4} \mathrm{U}$ prihod se ne uračunava zajamčena minimalna naknada, naknada za troškove stanovanja, mirovina do iznosa najniže, odnosno minimalne mirovine ostvarene za 40 godina mirovinskog staža, ortopedski dodatak, sredstva za uzdržavanje koje dijete ostvaruje na temelju propisa o obiteljskim odnosima, stipendija za školovanje učenika ili studenta dok traje redovito školovanje ili studiranje i doplatak za djecu.

${ }_{5}^{5}$ Pravilnik o izboru, načinu i postupku ostvarivanja prava osoba koje pružaju njegu i pomoć HRVI iz Domovinskog rata IOO\% I. skupine (NN, 43/O5.).

${ }^{6}$ Pet osnovica na temelju kojih se izračunava iznos drugih prava, a koja iznosi $500 \mathrm{kn}$.
} 
Ciljanje naknada prema pružateljima skrbi za starije i nemoćne osobe težak je zadatak jer je potrebno definirati: I) uvjete koje mora zadovoljavati primarni pružatelj skrbi; 2) razinu skrbi (broj sati tjedno); 3) odnos između pružatelja i primatelja skrbi (rodbinski odnos, zajedničko stanovanje); 4) intenzitet skrbi koju treba primatelj (OECD, 2OII). U praksi to može biti administrativno teško provjeriti, postoji mogućnost zlouporaba, te se uvjeti često mogu činiti nepravednima ili arbitrarnima. Pored toga, ako su naknade vezane uz dohodovni status, mogu destimulirati zaposlenost. Na kraju se postavlja i pitanje kad se radi o visoko intenzivnoj njezi - ne bi li tu njegu bolje pružali formalni njegovatelji s više iskustva i kvalifikacija. Primjerice, u Velikoj Britaniji manje od desetine njegovatelja prima naknadu za svoj rad zbog strogih uvjeta koji trebaju biti zadovoljeni.

Državni su rashodi (županijski i iz državnog proračuna) za pokrivanje razlike rashoda i prihoda decentraliziranih domova za starije i nemoćne u 20I4. iznosili oko I75 mil. kn, odnosno oko I.350 kn mjesečno po korisniku (NN, 7/I4.; MSPM, 2015). To je gotovo tromjesečni iznos doplatka za pomoć i njegu u kući, što znači da bi se u slučaju poslovanja domova bez gubitaka otvorio prostor za veće iznose doplatka ili druge mjere podrške neformalnoj skrbi. Valja napomenuti i da država sudjeluje u plaćanju cijene smještaja za one korisnike koji to nisu u mogućnosti (u potpunosti ili dijelom), čak ni uz pomoć obitelji ili prodaju vlastite imovine. Pravo na smještaj ne priznaje se osobi kojoj pomoć i njegu mogu pružiti članovi obitelji ili se pomoć i njega može osigurati na drugi način (čl. 93 Zakona o socijalnoj skrbi).

\section{Okvir I. Pravo na doplatak za pomoć i njegu i osobnu invalidninu HRVI iz Domovinskog rata}

Pravo na doplatak za pomoć i njegu imaju HRVI prve skupine i HRVI od II. do IV. skupine kojima je organizam oštećen i neovisno o vojnoj invalidnosti, a oštećenje je, zajedno s vojnom invalidnošću, jednako oštećenju organizma invalida I. skupine. Visina doplatka iznosi oko $3.800 \mathrm{kn}$ (IOO\% od osobne invalidnine invalida I. skupine) za prvi stupanj (HRVI iz Domovinskog rata od I. do IV. skupine koji su potpuno nesposobni za obavljanje svih životnih potreba i kojima je potrebna neprekidna njega i pomoć druge osobe), odnosno $2.500 \mathrm{kn}$ (66\% od osobne invalidnine invalida I. skupine) za drugi stupanj (ostali HRVI), a uvjeti za ostvarivanje propisani su čl. 67 ZOPHBDR-a i u biti se odnose samo na stupanj invaliditeta. Osobna invalidnina osnovno je pravo HRVI na osnovi oštećenja organizma i na temelju tog prava ostvaruju se sva ostala prava na osnovi oštećenja organizma. Osobna invalidnina određuje se prema skupini oštećenja organizma u koju je HRVI razvrstan, a najmanje je oštećenje 20\%. Mjesečni iznos osobne invalidnine invalida I. skupine određuje se u iznosu od II5\% od utvrđene proračunske osnovice, koja za 2015. iznosi 3.326 kn, što je 3.825 kn. Mjesečni iznos osobne invalidnine invalida od II. do X. skupine određuje se u postotku od osobne invalidnine invalida I. skupine, kako je propisano čl. 66 ZOPHBDR-a.

Posljednji podaci o HRVI koji prava ostvaruju prema ZOPHBDR-u raspoloživi su za 2OI3. (Vlada RH, 2OI4). Doplatak za pomoć i njegu druge osobe koristilo je $822 \mathrm{HRVI}$, za što je iz proračuna izdvojeno 32,3 mil. kn, odnosno oko 3.300 kn mjesečno po osobi. Tome treba dodati još i 27 hrvatskih mirnodopskih vojnih invalida za koje je izdvojeno 928,4 tisuće kn (oko 2.870 kn mjesečno po osobi). Osobnu invalidninu primalo je 57.238 HRVI, za što je iz proračuna 2013. namijenjeno 22O,I mil. kn. Najveći je broj korisnika HRVI iz X. skupine (2I.289), koji su prosječno mjesečno primali II5 kn. Za osobne invalidnine 856 hrvatskih mirnodopskih vojnih invalida iz proračuna je potrošeno 3,8 mil. kn. Prema čl. 84 ZOPHBDR-a, HRVI ima pravo na posebni doplatak u visini 50\% od pripadajućeg iznosa osobne invalidnine ako nije u radnom odnosu, ne prima mirovinu i naknadu plaće od dana stjecanja prava na profesionalnu rehabilitaciju kao i tijekom profesionalne rehabilitacije. U 20I3. bilo je 622 takvih korisnika, za koje je iz proračuna potrošeno oko 830 tisuća kn. Za ostala prava HRVI vidjeti ZOPHBDR.

\subsection{PODRŠKA U USKLAĐIVANJU NEFORMALNE SKRBI I ZAPOSLENOSTI}

U Hrvatskoj roditelji imaju pravo na dopust ili rad s polovicom radnog vremena radi skrbi i njege djeteta s težim smetnjama u razvoju. No, oko dvije trećine zemalja OECD-a omogućuje dopust i za njegu starijih i nemoćnih osoba, dok je rad s polovicom radnog vremena radi skrbi o starijima manje uobičajen (OECD, 2OII). 
Dopust za njegu obično je neplaćen, a ako je i plaćen, u većini je slučajeva ograničen na najviše mjesec dana ili za terminalne bolesti. Primjerice, u Belgiji je dopust plaćen čak godinu dana, a poslodavac ga može odbiti samo ako mu znatno ugrožava poslovanje. U Norveškoj plaćeni dopust obuhvaća cijeli iznos plaće. Neplaćeni dopust u nekim zemljama (npr. Francuska, Španjolska, Irska) može trajati i više od godine dana. No, u Španjolskoj i Irskoj poslodavac ga može odbiti zbog poslovnih razloga, dok su u Francuskoj kriteriji za ostvarivanje prava strogi: član obitelji kojem je potrebna njega, i koji živi s njegovateljem, mora biti najmanje 8o-postotni invalid. U Nizozemskoj neplaćeni dopust može trajati tri mjeseca, a u Austriji i Njemačkoj šest mjeseci, s time da je u Austriji ograničen samo na njegu terminalno bolesnih članova obitelji.

Iako imaju mogućnost korištenja dopusta za njegu, zaposlenici ga oklijevaju koristiti jer se boje da će im to utjecati na karijeru i dohodak. Stoga radije koriste bolovanje ili godišnji odmor, ako se radi o njezi niskog intenziteta. No, ljudi koji pružaju intenzivnu njegu svom partneru skloniji su koristiti dopust za njegu. Istraživanja pokazuju da se na dopust češće odlučuju zaposlenici u javnom sektoru i u velikim poduzećima (OECD, 2OII). Također, u poduzećima čiji zaposlenici koriste dopust više je žena, djelatnici su kvalificiraniji i poduzeća su češće u sektoru usluga.

Pored dopusta za njegu, fleksibilno radno vrijeme također može pomoći njegovateljima da rade. Međutim, rad s nepunim vremenom ipak se uglavnom koristi za njegu djece jer zakoni u pravilu omogućuju rad s nepunim radnim vremenom samo roditelijma. U Nizozemskoj gotovo 90\% poduzeća omogućuje rad s nepunim radnim vremenom, ali samo se oko $5 \%$ rada s nepunim radnim vremenom koristi za njegu starijih i nemoćnih. U nekim zemljama postoji pravo automatskog prebacivanja s nepunog na puno radno vrijeme.

\subsection{OSTALI OBLIGI PODRŠKE}

Istraživanje za Australiju i Veliku Britaniju pokazalo je da financijska pomoć njegovateljima ne mijenja znatno negativan utjecaj njege na mentalno zdravlje njegovatelja (OECD, 20II). Stoga je važno pronaći načine za smanjenje psihičkog pritiska koji osjećaju njegovatelji. Najčešći oblik pomoći je usluga privremene njege radi predaha uobičajenog njegovatelja (respite care). Njegovatelji obično nerado "prepuštaju" člana obitelji nekom drugom, bilo zato što nemaju povjerenje u kvalitetu njege ili to ne mogu financijski podnijeti. Ponekad je problem dostupnost same usluge. Ipak, čini se kako ni privremena njega nema osobit utjecaj na psihičko zdravlje njegovatelja, osim kad se radi o intenzivnoj njezi, za njegovatelje koji su zaposleni i kad se njeguje osoba s kognitivnim problemima (Davies i sur., 200o).

Irska i Austrija imaju posebnu naknadu za privremenu njegu, a u većini zemalja radi se samo o raspoloživoj usluzi koju financira obitelj. U Švedskoj općine omogućuju besplatnu privremenu njegu kod kuće. Njegovateljima također nude boravak u hotelu na dan-dva dok netko drugi brine o članu njihove obitelji. U Hrvatskoj je najbliža usluzi privremene njege socijalna usluga boravka (čl. 86 Zakona o socijalnoj skrbi). Boravak može biti cjelodnevni i poludnevni, a može se priznati jedan ili više dana u tjednu, ili sve radne dane u tjednu. Obično ga pružaju domovi za starije i nemoćne osobe i obiteljski domovi. Cjelodnevni boravak može trajati od šest do deset sati, a poludnevni od četiri do šest sati dnevno. U tom se vremenu korisnicima omogućuje prehrana, održavanje osobne higijene, briga o zdravlju, njega itd. ovisno o utvrđenim potrebama i izboru korisnika.

Boravak je 20I4. koristilo 38 osoba koje zbog starosti ili nemoći ne mogu samostalno skrbiti o osnovnim životnim potrebama (MSPM, 2OI5). Zakon također omogućuje privremeni smještaj djeteta i odrasle osobe (čl. 92) kako bi se njegovatelji odmorili, ali to je rezervirano samo za osobe koje imaju zakonski status njegovatelja, u pravilu za roditelje. Za tu je svrhu 20I4. privremeni smještaj koristilo 77 djece i 3 odrasle osobe.

Stres njegovatelja može se ublažiti i savjetovanjem sa zdravstvenim djelatnicima (OECD, 2OII), obično na lokalnoj razini vlasti i u nevladinom sektoru na dragovoljnoj osnovi. Irska je otišla korak dalje s programom "Skrb o skrbnicima" koji nudi tečajeve o potrebnim vještinama za neformalnu njegu. U 
Nizozemskoj njegovatelje posjećuju i telefonski kontaktiraju socijalni radnici kako bi spriječili psihičke probleme kod njegovatelja, osobito u početnim mjesecima njege. Dodatnu korist njegovatelji mogu imati od internetskih stranica ili brošura u kojima su objedinjene informacije o svim raspoloživim uslugama. U Škotskoj se liječnike obiteljske medicine potiče da identificiraju pružatelje neformalne skrbi, oforme registre, te dijele materijale o skrbi sa svim relevantnim informacijama. U Hrvatskoj se informacije o uslugama za starije osobe mogu pronaći na Središnjem državnom portalu i internetskim stranicama Ministarstva socijalne politike i mladih, te u centrima za socijalnu skrb. Zadarska županija je npr. pripremila koristan "Vodič za pod stare dane", a Karlovačka županija "Katalog informacija za osobe treće životne dobi Karlovačke županije". No, nigdje nema ničeg izričito vezanog uz neformalnu skrb.

U Hrvatskoj zdravstveno osigurane osobe mogu koristiti zdravstvenu njegu u kući.7 Pravo na tu uslugu imaju nepokretne ili teško pokretne osobe, kronični bolesnici u fazi pogoršanja i komplikacija, osobe s prolaznim ili trajnim zdravstvenim problemima koje se ne mogu same brinuti o sebi, koje su imale složenije operativne zahvate i bolesnici u terminalnoj fazi bolesti. Provođenje zdravstvene njege uključuje i poduku osobe te članova njezine obitelji o provođenju postupaka zdravstvene njege.

Zdravstvenu njegu u kući 20I4. koristilo je IOo.48I osoba, pri čemu najveći broj njih (oko 25\%) u dobnoj skupini od 75 do 84 godine (HZJZ, 2015). Ukupni udio starijih od 65 godina bio je $56 \%$. Gotovo polovica korisnika su nepokretne osobe. Najviše je kućnih posjeta (444 tisuće) bilo radi kompletne zdravstvene njege nepokretnog ili slabo pokretnog bolesnika, dok je obuka obitelji provedena u oko I2O tisuća posjeta. Osobe koje su teško pokretne ili potpuno nepokretne mogu primati i fizikalnu terapiju u kući, a uvjeti za ostvarivanje tog prava propisani su posebnim pravilnikom. ${ }^{8}$ Postoji i patronažna zaštita koju provode više medicinske sestre patronažnog smjera. Najveći broj posjeta u 20I4. (76I.308) bio je kroničnim bolesnicima u svrhu uputa i demonstracije određenih postupaka samokontrole i prevencije komplikacija osnovne kronične bolesti te provođenja terapijskih postupaka kod teško pokretnih i nepokretnih osoba.

\section{ZAKLJUČNA RAZMATRANJA I PREPORUKE}

Prema projekcijama Europske komisije, 206o. gotovo trećina hrvatskog stanovništva bit će starija od 65 godina, a oko desetine starije od 80 godina (EC, 20I5a). Uz starenje stanovništva, sve je manji broj djece u obitelji i povećava se broj razvoda i samačkih kućanstava. Prema podacima iz posljednjeg Popisa stanovništva, u Hrvatskoj je oko četvrtina kućanstava samačka, a polovicu njih čine stariji od 65 godina. Migracije su dodatno negativno utjecale na demografsku strukturu seoskih odnosno izvangradskih naselja. Na kraju, do 206o. porast će stopa participacije (udio aktivnog u radno sposobnom stanovništvu) žena u dobi od 55 do 64 godine za I7 postotnih bodova i iznositi 50\% (EC, 2OI5a). Navedeni čimbenici utječu na buduće smanjenje broja potencijalnih pružatelja neformalne skrbi. Ako se godišnje samo I\% funkcionalno ovisnih osoba u Hrvatskoj prebaci iz neformalne u formalnu skrb, 2030. će se broj osoba koje primaju formalnu institucionalnu skrb udvostručiti, a isto će biti i s brojem osoba koje primaju formalnu kućnu skrb (EC, 2015a). Time bi se udio rashoda za dugotrajnu skrb u BDP-u povećao s o,4\% (u 2013.) na $0,8 \%$ (2030.).

U Strateškom planu Ministarstva socijalne politike i mladih za razdoblje 2015.-2017.(MSPM, 20I4a), jedan je od ciljeva razvoj izvaninstitucionalnih oblika skrbi za starije osobe, osobito u njihovim domovima i lokalnim zajednicama radi što duljeg života u vlastitom okruženju i unapređenja kvalitete života. U suradnji s lokalnim i područnim samoupravama, te organizacijama civilnog društva, Ministarstvo želi nastaviti pružati i razvijati ponudu socijalnih usluga za samostalni život starijih osoba kod kuće, kao i

\footnotetext{
${ }^{7}$ Pravilnik o uvjetima i načinu ostvarivanja prava iz obveznog zdravstvenog osiguranja na zdravstvenu njegu u kući osigurane osobe. Narodne novine, 88/IO, I/II, I6/II, 87/II, 38/I3, 49/I3 i 93/I3, 62/I5, 77/I5.

8 Pravilnik o uvjetima i načinu ostvarivanja prava iz obveznog zdravstvenog osiguranja za bolničko liječenje medicinskom rehabilitacijom i fizikalnom terapijom u kući. Narodne novine, 46/o7, 64/o8, 9I/o9, II8/o9.
} 
stručnu pomoć prilikom zadržavanja starijih u krugu obitelji. Pritom je naglasak stavljen na socijalnu uslugu pomoći u kući.

Iako neformalna skrb može pomoći u smanjenju dugoročnih državnih rashoda, ipak treba imati na umu da može imati i negativne posljedice na pružatelje skrbi. Bonsang (2009) je dokazao da je u slučaju osoba s visokim invaliditetom, koje zahtijevaju vrlo intenzivnu njegu, neformalna skrb koju pružaju djeca svojim roditeljima slab supstitut formalnoj skrbi. Ipak, kad obitelj može brinuti o starijim i nemoćnim članovima, treba im pomoći:

- poticati fleksibilne radne sporazume, osobito kako njega starijih ne bi njegovatelje odvela u prijevremenu mirovinu;

- razmotriti uvođenje dopusta za njegu starijih i nemoćnih osoba, ali pritom dobro razmisliti o njegovu trajanju i o tome hoće li biti barem dijelom plaćen;

- intenzivirati socijalnu uslugu boravka, možda je i financijski potpomognuti, ali ciljati prema onima koji pružaju intenzivnu skrb i koji su zaposleni;

- prepoznati njegovatelje i pomoći im savjetima, u čemu bi za početak mogli pomoći liječnici obiteljske medicine i centri za socijalnu skrb;

- na jednom mjestu pružiti sve informacije za pružatelje neformalne skrbi;

- dobro koordinirati formalnu i neformalnu skrb.

\section{LITERATURA}

Bonsang, E., 2009. Does informal care from children to their elderly parents substitute for formal care in Europe? Journal of Health Economics, 28 (I), I43-I54.

Davies, B., Fernandez, J.-L. i Normer, B., 200o. Equity and Efficiency Policy in Community Care: Needs, Service Productivities, Efficiencies and their Implications. Ashgate: University of Kent at Canterbury Personal Social Services Research Unit.

DZS, 20I3. Popis stanovništva, kućanstava i stanova 20II. godine. Zagreb: Državni zavod za statistiku.

EC, 2015. Country Report Croatia 2015. European Commission.

EC, 20I5a. The 2015 Ageing Report: Economic and budgetary projections for the 28 EU Member States (2013-2060). European Commission.

Gianelli, G. C., Mangiavacchi, L. i Piccoli, L., 20IO. GDP and the Value of Family Caretaking: How Much Does Europe Care? IZA Discussion Paper, No. 5046.

HZJZ, 2OI5. Hrvatski zdravstveno-statistički ljetopis za 20I4. godinu. Zagreb: Hrvatski zavod za javno zdravstvo.

HZMO, 2015. Statističke informacije, br. 4/20I4. Zagreb: Hrvatski zavod za mirovinsko osiguranje.

MSPM, 20I3. Katalog prava i usluga - starije i nemoćne osobe. Zagreb: Ministarstvo socijalne politike i mladih.

MSPM, 20I4. Strategija socijalne skrbi za starije osobe u Republici Hrvatskoj za razdoblje 20I4.-20I6. Zagreb: Ministarstvo socijalne politike i mladih.

MSPM, 20I4a. Strateški plan Ministarstva socijalne politike i mladih za razdoblje od 20I5. do 20I7. godine. Zagreb: Ministarstvo socijalne politike i mladih.

MSPM, 20I5. Godišnje statističko izvješće o primjenjivim pravima socijalne skrbi u 20I4. godini. Zagreb: Ministarstvo socijalne politike i mladih.

Odluka o minimalnim financijskim standardima za decentralizirano financiranje domova za starije i nemoćne osobe u 20I4. godini, NN 7/I4. Zagreb: Narodne novine. 
OECD, 20II. Help Wanted? Providing and Paying for Long-Term Care. Pariz: OECD.

Podgorelec, S. i Klempić, S., 2007. Starenje i neformalna skrb o starim osobama u Hrvatskoj. Migracijske i etničke teme, 23 (I-2), III-I34.

Pravilnik o uvjetima i načinu ostvarivanja prava iz obveznog zdravstvenog osiguranja za bolničko liječenje medicinskom rehabilitacijom i fizikalnom terapijom u kući, NN 46/o7, 64/o8, 9I/o9, II8/og. Zagreb: Narodne novine.

Pravilnik o uvjetima i načinu ostvarivanja prava iz obveznog zdravstvenog osiguranja na zdravstvenu njegu u kući osigurane osobe, NN 88/IO, I/II, I6/II, 87/II, 38/I3, 49/I3 i 93/I3, 62/I5, 77/I5. Zagreb: Narodne novine.

Vlada RH, 20I4. Izvješće o provedbi Zakona o pravima hrvatskih branitelja iz Domovinskog rata i članova njihovih obitelji za 2013. godinu. Zagreb: Vlada Republike Hrvatske.

Zakon o pravima hrvatskih branitelja iz Domovinskog rata i članova njihovih obitelji, NN 174/O4, 92/O5, O2/O7, I07/O7, 65/O9, I37/O9, I46/IO, 55/II, I4O/I2, I9/I3, 33/I3, I48/I3, 92/I4. Zagreb: Narodne novine.

Zakon o socijalnoj skrbi, NN 157/I3, 152/14, 99/15. Zagreb: Narodne novine.

Žganec, N., Rusac, S. i Laklija, M., 2008. Trendovi u skrbi za osobe starije životne dobi u Republici Hrvatskoj i u zemljama Europske unije. Revija za socijalnu politiku, I5 (2), I7I-I88. 